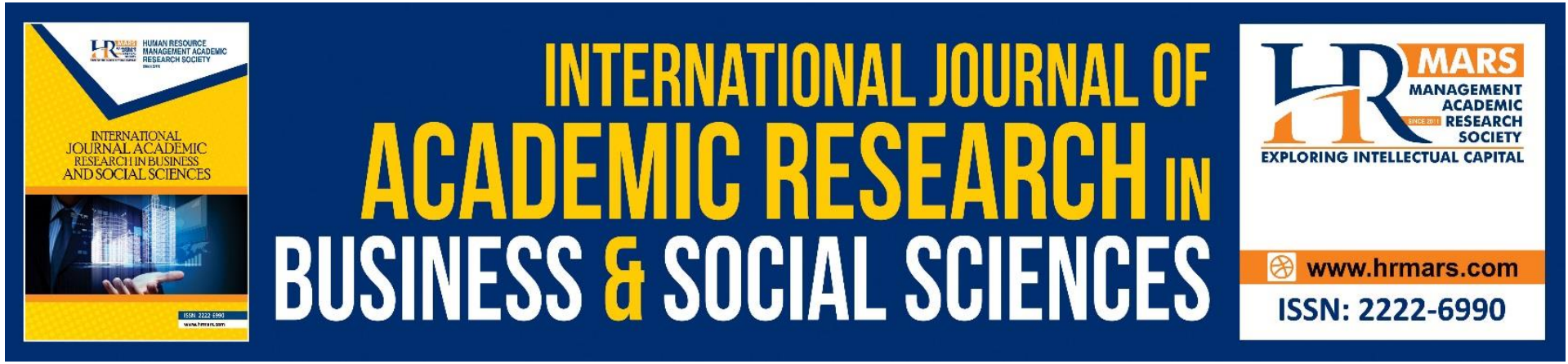

\title{
Implementation of The Critical Thinking Skills in Arabic Language Teaching and Learning: A Preliminary Study
}

\author{
Hanzalah Mohamed Nor, Ahmad Johari Sihes, Mas Hamidon
}

To Link this Article: http://dx.doi.org/10.6007/IJARBSS/v11-i9/11109

DOI:10.6007/IJARBSS/v11-i9/11109

Received: 06 July 2021, Revised: 30 July 2021, Accepted: 18 August 2021

Published Online: 10 September 2021

In-Text Citation: (Nor et al., 2021)

To Cite this Article: Nor, H. M., Sihes, A. J., \& Hamidon, M. (2021). Implementation of The Critical Thinking Skills in Arabic Language Teaching and Learning: A Preliminary Study. International Journal of Academic Research in Business and Social Sciences, 11(9), 1120-1128.

Copyright: (c) 2021 The Author(s)

Published by Human Resource Management Academic Research Society (www.hrmars.com)

This article is published under the Creative Commons Attribution (CC BY 4.0) license. Anyone may reproduce, distribute, translate and create derivative works of this article (for both commercial and non-commercial purposes), subject to full attribution to the original publication and authors. The full terms of this license may be seen at: http://creativecommons.org/licences/by/4.0/legalcode

Vol. 11, No. 9, 2021, Pg. 1120 - 1128

http://hrmars.com/index.php/pages/detail/IJARBSS

JOURNAL HOMEPAGE

Full Terms \& Conditions of access and use can be found at http://hrmars.com/index.php/pages/detail/publication-ethics 


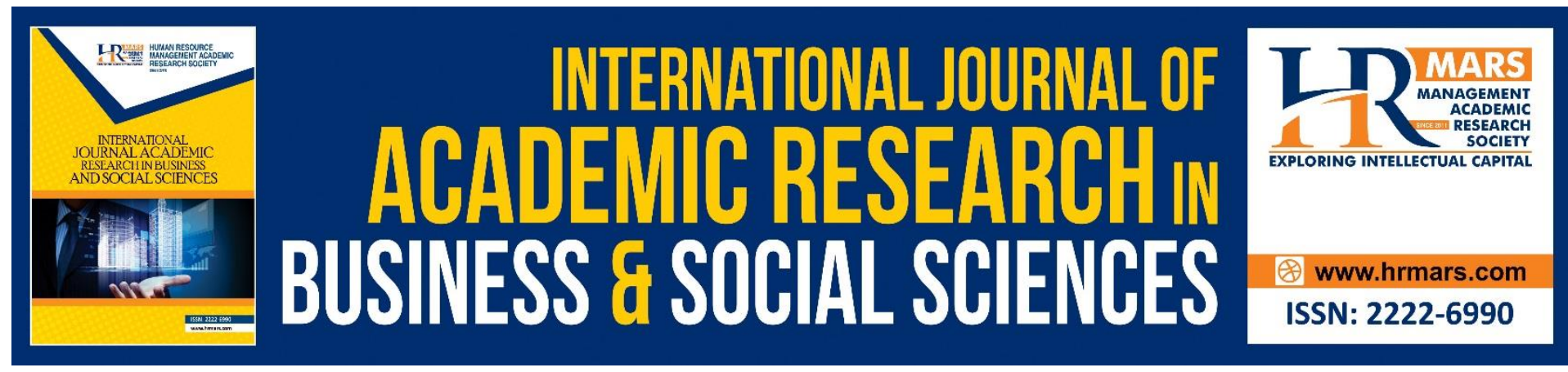

\title{
Implementation of The Critical Thinking Skills in Arabic Language Teaching and Learning: $A$ Preliminary Study
}

\author{
Hanzalah Mohamed Nor \\ School of Education, Faculty of Social Science and Humanities, \\ Universiti Teknologi Malaysia (UTM), 81310 Skudai Johor Bahru, Malaysia \\ Email: hanzalah3@graduate.utm.my
}

Ahmad Johari Sihes

School of Education, Faculty of Social Science and Humanities, Universiti Teknologi Malaysia (UTM), 81310 Skudai Johor Bahru, Malaysia

Email: p-joha@utm.my

\section{Mas Hamidon}

School of Education, Faculty of Social Science and Humanities, Universiti Teknologi Malaysia (UTM), 81310 Skudai Johor Bahru, Malaysia

Email: tesisphdutm2019@gmail.com

\begin{abstract}
Nowadays implementation of critical thinking skills in teaching and learning is considered one of the Arabic language teachers' tasks due to its high position in foreign language classrooms. In the context of Arabic teachers, the most important competence is the mastery of critical thinking skills in teaching and learning activities. Therefore, the aims of this study are to identify the level of competence of Arabic teachers in implementing the critical thinking skills in their teaching. A total of 30 Arabic teachers from secondary schools in Malaysia had answered survey comprising of 12 items from the sub-constructs of critical thinking skills. The quantitative data of the survey were analysed descriptively using the Statistical Package for Social Sciences (SPSS) Version 22.0 to present the frequency, percentage, mean and standard deviation. The findings revealed that Arabic language teachers have a moderately low level of critical thinking skills (Mean $=3.96$; SD $=0.462$ ). The data also highlighted that these Arabic teachers have not yet mastered the ability to make inferences, as evidenced by the skill's low mean score. It can be concluded form the study that teachers who come from various backgrounds and various educational levels showed the ability to think critically. This is due to their prior exposure to critical thinking skills in the classroom. The findings of this study indicate that Arabic teachers should develop critical thinking skills in order to be able to apply and develop this skill in their teaching activities. Furthermore, it offers a number of initiatives to improve teachers' knowledge and skills in infusing critical thinking in Arabic teaching as a
\end{abstract}


foreign language in order to meet the needs of the National Education System of the $21^{\text {st }}$ century.

Keywords: Critical Thinking Skills, Arabic Language, Teaching and Learning, $21^{\text {st }}$ Century.

\section{Introduction}

Nowadays, education has long been seen as a critical component in developing competent societies in the $21^{\text {st }}$ century. Empowerment of critical thinking skill is one of the important goals of the $21^{\text {st }}$ century education system. It is said that students do not only need intellectual mastery to survive, but also a competence that leads them to think critically (Glaze, 2018; Lindsey et al., 2014). Therefore, educational development should be able to support the development of students' critical thinking skills (Strauss, 2016). The development is indistinguishable from a number of studies that have sparked substantial debate on how to maintain quality improvement in the teaching process (Fauzi \& Pradipta, 2018; SpencerRodgers \& Cortijo-Ocaña, 2015). In fact, individuals with superior critical thinking skills will be able to compete not only on a national level, but also on a global scale in a wide range of fields.

Despite growing interests towards critical thinking skills in teaching education research, there have been relatively limited attempts to report the implementation of critical thinking skills in Arabic language teaching. Critical thinking skills are important constructs for analyzing a teacher's level of teaching and assisting them in developing a systematic and organized thought process in order to solve problems in the classroom and on a daily basis (California Critical Thinking Skill Test, 1998). Previous research has highlighted the variety of teaching skills patterns as a result of the expansion of Arabic education courses in Malaysia. Thus, this paper accentuates the need to enhance Arabic teachers' critical thinking skills in combination with foreign language competencies in Malaysia.

\section{Literature Review}

\section{Critical Thinking Skills in Arabic Language Teaching}

The ability to think critically has been identified as an important life skill. Recent researches suggest that specific training and practice of critical thinking skills in the high school classroom can help students perform better academically (Galinsky, 2010). According to UNICEF, UNESCO, and WHO, two of the ten core life skill strategies and practices are critical thinking and problem solving (World Health Organization, 1999). Today, critical thinking skills can also help students prepare for the rigors of university life while also assisting them in developing the competencies needed to compete economically in the global economy.

Critical thinking has just recently been introduced and has quickly risen to significance in foreign language teaching (FLT) contexts. Due to this reason, currently fostering critical thinking in learners is considered as one of the foreign language teachers' priorities. Many academics have presented various definitions for critical thinking such as Lipman (1991); Norris \& Ennis (1989); (Siegel, 1988). According to Elder \& Paul (1994), critical thinking refers to an individual's ability to take charge of their own thinking and generate appropriate criteria and standards for examining their own thinking.

Arabic teachers are among the practitioners who have a significant impact on how language learners learn. Therefore, one of their responsibilities is to help learners develop critical thinking abilities. According to Lipman (2003), apart from assisting students in progressing from one educational level to the next, teachers are responsible for encouraging students' critical thinking. Arabic teachers are responsible for assisting their students in developing 
critical thinking skills while learning the language. According to Mahyuddin et al., (2004), there is still a lot of potential for the future in terms of incorporating thinking skills into our curriculum. In reality, the development of critical thinking in the curriculum has spanned more than two decades in the education system in Malaysia. The majority of teachers unanimously recognize the importance of critical thinking in all areas of teaching in schools. However, the findings show that teachers are still not ready to teach critically as intended (Rajendran, 2010). This can be evident by the teaching practice of Arabic teachers is still traditional by emphasizing the skills of remembering and memorizing lesson content compared to thinking skills in the classroom(Fuad et al.,2017; Muirhead et al., 2016; Nicholas and Raider-Roth, 2016; Yunawati et al., 2016).

In line with this, the curriculum transformation of the education system continues to evolve to ensure that its goals remain relevant in line with the wave of educational challenges in the $21^{\text {st }}$ century towards producing human capital that meets the needs of the industry in the future. Accordingly, the teaching landscape of teachers needs to change drastically to produce critical thinking students based on the current needs. In addition, consideration of the diversity of teachers' teaching styles needs to be refined to implement better teaching. Therefore, teachers need to prepare themselves with the critical thinking competencies to increase the effectiveness of Arabic language teaching as desired.

\section{Research Methodology}

This study adopted a descriptive quantitative approach by utilizing surveys with simple random sampling to assess the level of critical thinking competence among Arabic language teachers at secondary schools in Malaysia. The instrument used was a questionnaire consisting of 12 items measured using a 5-Point Likert Scale. The items used in this questionnaire were adopted from the study of Hamat et al., (2007). Section A contains the respondents' demographic information such as gender, age, academic qualifications, options and experience in teaching Arabic, while part B contains 13 items related to the critical thinking competence of Arabic language teachers in teaching.

The data were analyzed using "Statistical Package for Social Science Version 22.0". The descriptive statistic was used to analyze the data to determine the level of critical thinking skills among Arabic teachers in teaching and learning activities. The data were analyzed in terms of frequency, percentage and mean to describe the study sample and answer the research questions. Table. 1 shows the interpretation analysis as expressed by Nunnally \& Berstein (1994), which are as follows:

Table 1. Interpretation Mean Score (Nunnally \& Berstein, 1994)

\begin{tabular}{ll}
\hline Mean Score & Interpretation \\
\hline $1.01-2.00$ & Low \\
$2.01-3.00$ & Moderate Low \\
$3.01-4.00$ & Moderate High \\
$4.01-5.00$ & High \\
\hline
\end{tabular}

\section{Research Findings}

\section{Respondent Profile Analysis}

Based on Table2, the analysis showed that the number of female teachers outnumbered male teachers with a total of $18(60 \%)$ and $12(40 \%)$ respectively. This phenomenon is a common 
occurrence where the capacity of the number of female teachers is dominant than male teachers in the education system in Malaysia.

In terms of age, a total of 1 teacher (19.5\%) was aged less than 25 years, 3 teachers (10\%) aged between 25 and 30 years, 6 teachers (20\%) aged between 31 and 35, 3 teachers (10\%) aged between 36 and 40 and 17 teachers (56.7\%) aged over 40 years. These findings show that teachers over the age of 40 are more likely to teach Arabic than their younger counterparts. This study revealed that experienced teachers were chosen to teach Arabic as foreign language in secondary schools.

Further analysis of respondents' profiles involves their academic qualifications. Based on the results, majority of the respondents has a Bachelor's degree, with 21 teachers (70\%) having a Bachelor's degree and 9 teachers (30\%) having a Master's degree. In terms of the options during the study, it was found that 17 teachers (56.7\%) were major in Arabic language and 11 teachers (36.7\%) were minor in Arabic language and 2 teachers (6.7\%) took other options. This indicates that the majority of the teachers took Arabic language as their major.

Table 2. Respondents' profile

\begin{tabular}{llll}
\hline Demography & $\begin{array}{l}\text { Descriptive } \\
\text { (N-30) }\end{array}$ & Frequency & $\begin{array}{l}\text { Percentage } \\
\text { (\%) }\end{array}$ \\
\hline Gender & Male & 12 & 40 \\
Age & Female & 18 & 60 \\
& Less 25 years & 1 & 3.3 \\
& 25-30 years & 3 & 10 \\
& 31-35 years & 6 & 20 \\
& 36-40 years & 3 & 10 \\
Academic & 40 years and above & 17 & 56.7 \\
qualification & Diploma & 0 & 0 \\
& Bachelor & 21 & 70 \\
& Master & 9 & 30 \\
Options & Doctorate & 0 & 0 \\
& Major Arabic & 17 & 56.7 \\
& Minor Arabic & 11 & 36.7 \\
Teaching & Others & 2 & 6.7 \\
experience & $<5$ years & 9 & $30 \%$ \\
& 5-10 years & 5 & $16.7 \%$ \\
& 11-15 years & 5 & $16.7 \%$ \\
& $>15$ years & 11 & $36.7 \%$ \\
\hline
\end{tabular}

\section{Descriptive Analysis}

This part aims to examine the main question, which is the level of critical thinking skills possessed by Arabic language teachers. The analysis is reported in the form of mean and standard deviation.

Table. 3 highlights that the level of competence of critical thinking skills of Arabic language teachers in teaching for each item is moderately high (Mean $=3.96 ; S D=0.462$ ). The item that represents the highest mean is "I always encourage students to be actively involved in the classroom" (Mean $=4.43 ; \mathrm{SD}=0.678$ ) which is at a high level. In terms of frequency and 
percentage, 16 people (53.3\%) strongly agree, 11 people (36.7 \%) agree, and 3 people (10\%) sometimes agree.

On the other hand, the item that obtained the lowest mean was "I encourage students to make appropriate inferences before making predictions" (Mean $=3.40 ; \mathrm{SD}=0.855$ ) which is at a moderately low level. In terms of frequency and percentage, a total of 3 teachers $(10 \%)$ stated strongly agree, 10 teachers (33.3\%) stated agree, 13 teachers (43.3\%) stated sometimes agree, and 4 teachers (13.3\%) stated disagree.

Table 3. Level of Critical Thinking Skills

\begin{tabular}{|c|c|c|c|}
\hline \multirow[t]{2}{*}{ Bil. } & \multirow[t]{2}{*}{ Items } & \multicolumn{2}{|c|}{ Teacher $(\mathrm{N}=30)$} \\
\hline & & Mean & SD \\
\hline 1 & $\begin{array}{l}\text { I ask students to characterize some of the things } \\
\text { or concepts learned }\end{array}$ & 3.8667 & .73030 \\
\hline 2 & $\begin{array}{l}\text { I ask students to compare the differences of } \\
\text { some things or concepts. }\end{array}$ & 3.9000 & .54772 \\
\hline 3 & $\begin{array}{l}\text { I ask students to think of as many solutions to a } \\
\text { question. }\end{array}$ & 3.9000 & .71197 \\
\hline 4 & $\begin{array}{l}\text { I ask students to characterize/ categorize things } \\
\text { as appropriate. }\end{array}$ & 4.0333 & .71840 \\
\hline 5 & $\begin{array}{l}\text { I ask students to arrange ideas in chronological } \\
\text { order of information effectively. }\end{array}$ & 3.8333 & 69893 \\
\hline 6 & I encourage students to analyze given reasons. & 3.8667 & .81931 \\
\hline 7 & $\begin{array}{l}\text { I encourage students to use analogies/ } \\
\text { comparisons in explaining things or concepts. }\end{array}$ & 3.7333 & .78492 \\
\hline 8 & $\begin{array}{l}\text { I encourage students to make connections } \\
\text { between small parts and the whole passage. }\end{array}$ & 3.8333 & 64772 \\
\hline 9 & $\begin{array}{l}\text { I encourage students to make appropriate } \\
\text { inferences before making predictions. }\end{array}$ & 3.4000 & .85501 \\
\hline 10 & $\begin{array}{l}\text { I always encourage students to be actively } \\
\text { involved in class. }\end{array}$ & 4.4333 & 67891 \\
\hline 11 & $\begin{array}{l}\text { I always encourage students to get involved in } \\
\text { PdP activities accompanied by critical activities. }\end{array}$ & 4.3000 & .74971 \\
\hline 12 & $\begin{array}{l}\text { I always encourage students to ask questions and } \\
\text { discuss in class. }\end{array}$ & 4.4000 & .67466 \\
\hline \multicolumn{2}{|c|}{ Total } & 3.9583 & .46152 \\
\hline
\end{tabular}

\section{Discussion}

The findings of this study suggest that teachers' critical thinking skills are still lacking. The interpretation of total mean which is moderately high, with mean value of 3.9583 indicates that the teachers' have moderate level of critical thinking ability. Therefore, based on the finding, the teachers' level of critical thinking skills failed to meet the required expectations. Nevertheless, despite the moderate level of critical thinking skills obtained from the statistical analysis, it is undeniable that Arabic teachers have began to put effort and carried forward the initiative to integrate critical thinking skills in their classroom. This is evident in the lessons where Arabic teachers encouraged active participation among their students by encouraging 
them to ask questions and answer them, and share their thoughts during teaching and learning activities, at the same time, motivating the students to think and act critically. The findings supported that Arabic language teachers have developed a few of critical thinking skills such as synthesizing, analyzing, applying and evaluating.

Other than that, the results also show that Arabic teachers have not yet mastered the skill of inference, and this is proven by the low mean value. Nevertheless, this study shows that Arabic language teachers have a good level of competence in other skills. These findings are supported by Elmouhtarim (2018) on the implementation of thinking skills in language education from the teacher's perspective, indicating that teachers have high critical and creative thinking skills. An understanding of the concept of thinking skills needs to be mastered by teachers given the factors influencing the teaching effectiveness of teachers.

As a result, one of the attempts to reach success and excellence in the subject of Arabic as a foreign language is to engage critical thinking skills in teaching and learning activities. Sieglová (2017) supported that success in a subject will not be achieved if teachers continue to employ traditional techniques that ignore elements of students' thinking skills. This is because thinking skills is an important element in mastering a skill and influencing students' achievement.

All of these implications lead to the conclusion that critical thinking skills in the classroom is a quality indicator and will contribute to the development of a generation of competent and confident students. Furthermore, cultivating a critical thinking environment would definitely empower students and de-emphasize so-called spoon-feeding teaching dependent on the presentation and receiving of ready-made content.

\section{Conclusion}

In today's curriculum, critical thinking has become a contentious issue. It is seen as an essential $21^{\text {st }}$ century skill. Before analyzing information and making judgments, students must have critical thinking skills that include interpreting information through logical reasoning and analysis, viewing things from different viewpoints, and problem-solving. Furthermore, fostering critical thinking competency is an important cognitive skill that should be included in the curriculum. As critical thinking skills cannot be taught separately, they must be integrated with language skills. Students must be aware of these reflective skills and practice applying critical thinking in a variety of contexts on a daily basis. Teachers' responsibility should not be ignored either. It is crucial to create an environment that encourages inquisitiveness, truth seeking, and questioning so that reading material or any type of information can be fully evaluated, analyzed, and understood.

This paper shows that teachers who possess good critical thinking skills are needed in the teaching of Arabic language. However, more focus must be given to other skills, which are still required to be improved. To encourage students to participate actively and develop critical thinking skills throughout the teaching and learning process, student-centered teaching methods must be enhanced. Richard (2006), stated that educators are also responsible in nurturing these critical thinking skills across subjects. Developing the components of critical thinking skills in Arabic teaching is significant and fulfills the current needs. 


\section{References}

Sieglová, D. (2017). Critical Thinking for Language Learning and Teaching: Methods for the 21st Century. Cross-Cultural Business Conference, May. https://www.researchgate.net/publication/315697174

Elder, L., \& Paul, R. (1994). Critical thinking: Why we must transform our teaching. Journal of Developmental Education, 18(1), 34.

Elmouhtarim, S. (2018). Integrating Critical Thinking Skills in Reading Courses at the University Level The Case of Faculty of Letters and Humanities, Beni-Mellal, Morocco. Arab World English Journal, 9(3), 331-344. https://doi.org/10.24093/awej/vol9no3.22

Fauzi, A., \& Pradipta, I. W. (2018). Research methods and data analysis techniques in education articles published by Indonesian biology educational journals. Jurnal Pendidikan Biologi Indonesia, 4(2), 123-134. https://doi.org/10.22219/jpbi.v4i2.5889

Fuad, N. M., Zubaidah, S., Mahanal, S., \& Suarsini, E. (2017). Improving junior high schools' critical thinking skills based on test three different models of learning. International Journal of Instruction, 10(1), 101-116. https://doi.org/10.12973/iji.2017.1017a

Galinsky, E. (2010). Mind in the making: The seven essential life skills every child needs. New York, NY: Harper Collins Publishing.

Glaze, A. L. (2018). Teaching and learning science in the 21st century: Challenging critical assumptions in post-secondary science. Education Sciences, 8(1), 1-8. https://doi.org/10.3390/educsci8010012

Hamat, M. F., Abdullah, W. S. W., Seman, A. C., Kasim, T. S. A. T., Rahman, S. M. H. S. A., Abd Latif, F., \& Husin, F. C. (2007). Penerapan Pemikiran Kritis Menerusi Silibus Pendidikan Islam, Kurikulum Bersepadu Sekolah Menengah (KBSM): Kajian di SMKA Negeri Melaka. Jurnal Akidah \& Pemikiran Islam, 8(1), 207-240.

Lindsey, R. V., Shroyer, J. D., Pashler, H., \& Mozer, M. C. (2014). Improving Students' LongTerm Knowledge Retention Through Personalized Review. Psychological Science, 25(3), 639-647. https://doi.org/10.1177/0956797613504302

Lipman, B. L. (1991). How to decide to...: Modeling limited rationality. Econometrica: Journal of the Econometric Society, 1105-1125.

Lipman, M. (2003). Thinking in education. Cambridge university press.

Nicholas, M. C., \& Raider-Roth, M. (2016). A Hopeful Pedagogy to Critical Thinking. International Journal for the Scholarship of Teaching and Learning, 10(2), 2. https://doi.org/10.20429/ijsotl.2016.100203

Norris, S. P., \& Ennis, R. H. (1989). Evaluating Critical Thinking. The Practitioners' Guide to Teaching Thinking Series. Critical Thinking Press and Software.

Nunnally, J. U. M. C., \& Berstein, I. H. (1994). Psycometric theory. New York: McGraw Hill.

Mahyuddin, R., Pihie, Z. A. L., Elias, H., \& Konting, M. M. (2004). The Incorporation of Thinking Skills in the School Curriculum. Kajian Malaysia, 22(2), 23-33.

http://www.usm.my/km/22-2-04/KM-

ART_2_Thinking_Skills_In_The_School_Curriculum_(41-51).pdf

Science, T. A. (1992). 14th International Conference on Thinking ( ICOT 2009 ) Guest Editors : Journal of Social Sciences \& Humanities, 18(Dec), 1-210.

Siegel, H. (1988). Educating reason: Rationality, critical thinking, and education. New York: Routledge.

Spencer-Rodgers, J., \& Cortijo-Ocaña, A. (2015). Educational Research on Diversity and Quality Improvement in Education. Journal of New Approaches in Educational Research, 4(1), 1-1. https://doi.org/10.7821/naer.2015.1.121 
Strauss, D. (2016). How critical is "critical thinking"? South African Journal of Philosophy, 35(3), 261-271. https://doi.org/10.1080/02580136.2016.1191853

Yunawati, S. A., Corebima, D., \& Indriwati, S. E. (2016). The Analysis of Teaching Habit Effect Based on Conventional Learning in Empowering Metacognitive Skills and Critical Thinking Skills of Senior High School Students in Malang, Indonesia. International Journal of Academic Research and Development, 1(5), 64-69. 